\title{
Effect of mineral matters in biomass on the gasification rate of their chars
}

\author{
Toshimitsu Suzuki $\cdot$ Hiroshi Nakajima $\cdot$ \\ Na-oki Ikenaga $\cdot$ Hirokazu Oda $\cdot$ Takanori Miyake
}

Received: 28 September 2010 /Revised: 24 January 2011 / Accepted: 25 January 2011 /Published online: 15 February 2011

(C) Springer-Verlag 2011

\begin{abstract}
In order to develop the effective utilization of biomass, the gasification behavior (changes in gasification rates against conversion) of various chars prepared from biomass at $1,000^{\circ} \mathrm{C}$ was studied. The gasification rate of char with $\mathrm{CO}_{2}$ measured at $900^{\circ} \mathrm{C}$ by a thermogravimetric balance was affected by the content of indigenous mineral matter such as calcium and potassium. The gasification behavior of chars were classified into following three groups: (1) the gasification rate reached a maximum in the higher conversion region, (2) the gasification rate profile showed two peaks around char conversion of 0.2 and 0.6 or higher, (3) the gasification rate profile fitted the random pore model. An increase in the gasification rate in a higher char conversion region was attributed to the promotion effect of the potassium catalyst. The number of active centers in the char was obtained by the $\mathrm{O}_{2}$ uptake at $200^{\circ} \mathrm{C}$ using pulse technique. The number of active sites was increased by potassium and calcium in biomass and the amount of $\mathrm{O}_{2}$ uptake well correlated the char gasification rate.
\end{abstract}

Keywords $\mathrm{CO}_{2} \cdot$ Gasification rate $\cdot$ Biomass $\cdot$ Mineral matter

\section{Introduction}

In the third session of the Conference of the Parties to the United Nations Framework Convention on Climate Change (COP3), developed countries were obligated to decrease their emission of greenhouse gases. To achieve the treaty's

T. Suzuki $(\bowtie) \cdot$ H. Nakajima $\cdot$ N.-o. Ikenaga $\cdot$ H. Oda $\cdot$ T. Miyake Department of Chemical, Energy and Environmental Engineering, Kansai University,

3-3-35 Yamate, Suita,

Osaka, Japan 564-8680

e-mail: v902360@kansai-u.ac.jp goal, countries have to develop their use of non-fossil fuels to replace fossil fuels.

Biomass is one of such alternatives to reduce $\mathrm{CO}_{2}$ emission. Biomass is composed of similar organic sources as coal, but it is a carbon neutral source. The $\mathrm{CO}_{2}$ concentration on the land surface is considered not to vary in spite of releasing $\mathrm{CO}_{2}$ by combustion of biomass, since $\mathrm{CO}_{2}$ is absorbed by photosynthesis when new biomass grows. Clean development mechanism (CDM) projects, as defined by the Kyoto Protocol, could be achieved by getting more than $40 \%$ of energy sources from biomass [1]. In addition, to overcome shortage of fossil fuels in the near future, use of renewable biomass as alternative energy sources became more important [2]. One of such projects related to effective use of biomass is construction of power generation plants using biomass. An integrated system such as gasification and power plant is more effective to reduce $\mathrm{CO}_{2}$ emissions than simple thermal use [3, 4]. Also, outline of biomass gasification and problems to be solved was recently summarized [5].

In the gasifier, a gasification agent such as $\mathrm{O}_{2}$, air, steam, and $\mathrm{CO}_{2}$ are used, and the reaction of $\mathrm{CO}_{2}$ and $\mathrm{H}_{2} \mathrm{O}$ with biomass char is the rate-determining step. Therefore, analysis of the reaction of char with $\mathrm{CO}_{2}$ and $\mathrm{H}_{2} \mathrm{O}$ is an important factor in designing a gasification plant.

In terms of carbon gasification, Walker et al. proposed the idea of free carbon active site $\left(\mathrm{C}_{\mathrm{f}}\right)$, and active surface area which corresponds to the number of active sites. The active surface area has a good correlation with the reaction rate of carbon $[6,7]$. The mechanism of non-catalytic carbon gasification processes are understood as:

$$
\begin{aligned}
& \mathrm{C}_{\mathrm{f}}+\mathrm{H}_{2} \mathrm{O} \rightarrow \mathrm{C}(\mathrm{O})+\mathrm{H}_{2} \\
& \mathrm{C}_{\mathrm{f}}+\mathrm{CO}_{2} \rightarrow \mathrm{C}(\mathrm{O})+\mathrm{CO} \\
& \mathrm{C}(\mathrm{O}) \rightarrow \mathrm{CO}+\mathrm{C}_{\mathrm{f}}
\end{aligned}
$$


where $\mathrm{C}_{\mathrm{f}}$ and $\mathrm{C}(\mathrm{O})$ denote a free carbon active site and an occupied active site. Desorption of $\mathrm{CO}$ from $\mathrm{C}(\mathrm{O})$ regenerates a free carbon active site.

These processes in biomass chars are essentially identical to those reported to carbon or coal char gasification. A large number of studies on coal char gasification have been carried out. Takeda et al. reported that the gasification rate is affected by the rank of coal, carbonization conditions, and the graphite structure developed during gasification at high temperature [8]. Furthermore, use of catalyst for coal gasification is proposed in order to decrease gasification temperature without changing gasification rate. Transition metals (Ni, Fe) [9-14], alkali metals ( $\mathrm{Li}, \mathrm{Na}, \mathrm{K}, \mathrm{Rb})$ [1519], and alkaline earth metals (Ca, $\mathrm{Mg}, \mathrm{Sr}, \mathrm{Ba})$ [17, 20, 21] showed high activities in coal char gasification. In addition, mineral matter contained in coal affects the reactivity of coal. Hashimoto et al. investigated steam gasification of 18 different raw and demineralized coals, and found that the gasification rate of low rank coals $(\mathrm{C}<80 \%)$ was decreased by demineralization, and that the gasification rate of high rank coal did not change and rather, the rate of some coals increased [22]. Catalysts for biomass gasification were summarized by Sutton et al. [23].

Many attempts have been made to develop a kinetic model for $\mathrm{H}_{2} \mathrm{O}$ and $\mathrm{CO}_{2}$ gasification behavior of coal chars, i.e., the grain model [24], the percolation model [25], or the random pore model (RPM) [26]. In biomass gasification, however, the presumptions based on the original model derivation do not match experimental value, especially not with catalyzed char gasification [27]. Although the deviation from gasification behavior occurred in a high conversion region, Standish et al. pointed out that it might emerge from a sudden disintegration of porous structure during gasification [28]. Hamilton et al. proposed the reason for the reaction rate being at a maximum at around conversion of 0.7 was surface saturation of biomass char by the alkali catalyst [29]. This suggestion, however, is not consistent with other literature [30] on saturation effects in alkali-catalyzed gasification of biomass chars. It is claimed that the initial reaction rate of chars impregnated with alkali carbonates increases uniformly with the metal-to-carbon atom ratio $(\mathrm{M} / \mathrm{C})$, up to a saturation level, typically, of $\mathrm{M} / \mathrm{C}=0.1$. Although initial atomic $\mathrm{M} / \mathrm{C}$ ratio of chars impregnated with alkali metal is about 0.007 , the saturation effects at $\mathrm{M} / \mathrm{C}=0.1$ may not be encountered below $93 \%$ of the carbon consumed by the gasification reaction. Struis et al. have insisted that anomalous reaction rate behavior with alkali-catalyzed char merely depicts a superposition of changes of structure (micropore domain) and catalytic effects [27]. Recently Zahng et al. studied $\mathrm{H}_{2} \mathrm{O}$ gasification of various biomass chars and reported the deviation from RPM [31].

All the mineral matters in biomass are composed in part of tissue. The char from plants is considered to be more homogeneous than that from coal. In addition, demineralization of biomass can easily be carried out simply by immersing it in dilute $\mathrm{HCl}$.

From this standpoint, the study of $\mathrm{CO}_{2}$ gasification of various biomass chars looks promising in terms, not only of effective utilization of biomass, but also of gasification of carbon sources, and specifically catalytic gasification.

In this paper, we describe the $\mathrm{CO}_{2}$ gasification behavior of various wood chars and examine them to understand the effect of the mineral matters contained in biomass on the gasification rate.

\section{Experimental}

\subsection{Feedstock}

Japanese cedar wood, fig tree, umemodoki (Ilex serrata), Japanese oak, mukuge (Hibiscus syriacus), eucalyptus, cherry tree, satsuki (Rhododendron indicum), chopstick (Betula platyphylla), nandina, and pine were used as woody biomass samples; bean curd, coffee bean residue, and tea leaves as food wastes; rice straw as herbaceous biomass; and chlorella, rittorale, and spirulina as microalgae biomass. Australian Yallourn coal (C:67.2, H: 4.8 daf\%, ash 1.1\%) and Japanese Taiheiyo coal (C: 74.5, H: 5.2 daf\%, ash $12.0 \%$ ) were used for comparison with biomass.

\subsection{Acid treatment}

Since mineral matters in biomass were known to behave as catalysts for biomass gasification, to eliminate effect of mineral matters in biomass, demineralization of them by acid treatment was done as follow: $5 \mathrm{~g}$ of ground biomass $(<1 \mathrm{~mm})$ was demineralized using $100 \mathrm{~mL}$ of $1 \mathrm{M}$ hydrochloric acid for $12 \mathrm{~h}$ under supersonic radiation. Then the samples were washed with pure water until $\mathrm{Cl}^{-}$free and dried in vacuo at $70^{\circ} \mathrm{C}$ for $24 \mathrm{~h}$.

\subsection{Impregnation of catalysts}

To understand catalytic behavior of respective alkali and alkaline earth metal, the following metals were impregnated with acid-treated biomass samples.

$\mathrm{Na}_{2} \mathrm{CO}_{3}, \mathrm{~K}_{2} \mathrm{CO}_{3}, \mathrm{Ca}(\mathrm{OH})_{2},(\mathrm{CHCOO})_{2} \mathrm{Ca}_{2} \mathrm{O}, \mathrm{Mg}$ $\left(\mathrm{NO}_{3}\right)_{2} \quad 6 \mathrm{H}_{2} \mathrm{O}$, and $\mathrm{Fe}\left(\mathrm{NO}_{3}\right)_{3} \quad 9 \mathrm{H}_{2} \mathrm{O}$ were reagent grade chemicals from Wako Pure Chemical Industries Ltd. These salts were selected from solubility in water and rapid decomposition of anions during carbonization stage.

A solution of $\mathrm{Na}_{2} \mathrm{CO}_{3}, \mathrm{~K}_{2} \mathrm{CO}_{3}, \mathrm{Ca}(\mathrm{OH})_{2},(\mathrm{CHCOO})_{2} \mathrm{Ca}$ $\mathrm{H}_{2} \mathrm{O}, \mathrm{Mg}\left(\mathrm{NO}_{3}\right)_{2} 6 \mathrm{H}_{2} \mathrm{O}$, or $\mathrm{Fe}\left(\mathrm{NO}_{3}\right)_{3} 9 \mathrm{H}_{2} \mathrm{O}$ was mixed with a $0.5 \mathrm{~g}$ of HCl-treated biomass or a $0.1 \mathrm{~g}$ of char. The slurry 
was stirred for $24 \mathrm{~h}$, and then the excess water was removed at $70^{\circ} \mathrm{C}$ under reduced pressure using a rotary evaporator.

\subsection{Char preparation}

A certain amount ( 5 to $0.1 \mathrm{~g}$ ) of untreated or HCl-treated and/or metal salts-loaded samples were devolatilized at $1,000^{\circ} \mathrm{C}$ at a heating rate of $10^{\circ} \mathrm{C} / \mathrm{min}$ holding time of $2 \mathrm{~h}$ (at $1,000^{\circ} \mathrm{C}$ ) under flowing nitrogen atmosphere. Using an alumina reactor tube, a $5 \mathrm{~g}$ of biomass sample in a ceramic boat was set and the reactor was inserted into a furnace quipped with a programmable temperature controller. The obtained chars were pulverized to pass through a 100-mesh screen.

\subsection{Analyses and characterization of char}

Alkali metals, alkaline earth metals, and iron contents were obtained by inductively coupled plasma atomic emission spectrometry (Shimadzu ICP-1000 III) and atomic absorption spectrometry (Shimadzu AA-6800) from the recovered $\mathrm{HCl}$ solution after treating biomass samples. Silicon and aluminum contents were measured by a sequential X-ray fluorescence spectrometer (Shimadzu SXF-1200BF) from biomass ash. Anhydrous lithium tetraborate (type II) and ash were set in a sample holder made from polyvinyl chloride, which was pressurized at $25 \mathrm{MPa}$ for $10 \mathrm{~min}$. Monochromatized X-rays were irradiated from a $\mathrm{Rh} \mathrm{K} \alpha$ target (tube voltage, $40 \mathrm{kV}$; tube current, $70 \mathrm{~mA}$ ).

The surface areas of the chars were measured by the BET method using an automatic gas adsorption apparatus (Yuasa Ionics Co., Autosorb-1), applying adsorption isotherms of nitrogen at $-196^{\circ} \mathrm{C}$. Surface areas of selected biomass chars were measured by the Dubinin-Astakhov method applying adsorption isotherms of carbon dioxide at $0^{\circ} \mathrm{C}$.

The true density measurement was performed by vapor replacement method with $\mathrm{He}$ using a Micromeritics gas pycnometer (Shimadzu Accupyc 1300).

The structure of chars was analyzed by powder X-ray diffraction method using an X-ray diffractrometer (Shimadzu $\mathrm{XRD}-6000$ ) with monochromatized $\mathrm{Cu} \mathrm{K} \alpha$ radiation (tube voltage, $40 \mathrm{kV}$; tube current, $30 \mathrm{~mA}$ ).

\subsection{Gasification}

Gasification of char was conducted using a thermogravimetric analyzer (Shimadzu TGA-50). A $10 \mathrm{mg}$ of char was placed on the platinum pan. Heating was programmed at a heating rate of $20^{\circ} \mathrm{C} / \mathrm{min}$ from room temperature to 800 $1,000^{\circ} \mathrm{C}$ under $\mathrm{N}_{2}$ atmosphere $(30 \mathrm{~mL} / \mathrm{min})$. After holding for $1 \mathrm{~h}$ at a predetermined temperature, $\mathrm{N}_{2}$ flow was switched to $\mathrm{CO}_{2}(30 \mathrm{~mL} / \mathrm{min})$ and weight loss was monitored, and this point was set as reaction time zero. Remaining carbon was burned off by air after gasification with $\mathrm{CO}_{2}$. Conversion $X$ and the gasification rate $R$ during gasification were calculated as follows:

$X=\left(M_{0}-M_{t}\right) /\left(M_{0}-M_{\mathrm{ash}}\right)$

$R=1 /(1-X)(d X / d t)$

where $M_{0}, M_{t}, M_{\text {ash }}$ are initial weight, weight at time $t$, and weight of ash, respectively.

Gasification time is defined as the reaction time (minutes) required to reach a char conversion of $X=0.95$. Reproducibility of TG analyses were in the range of $\pm 3 \%$.

\subsection{Evaluation of gasification rate using reaction model}

An attempt to fit the gasification rate to the random pore model proposed by Bhatia and Pulmutter was carried out to describe gasification behavior [26]. The kinetic model assumed that the reaction proceeds randomly on the surface of pores in the solid char. The degree of pore erosion (widening and pitting of pore by carbon loss during gasification) in the reaction progress is represented as

$S=S_{0}(1-X)(1-\psi \ln (1-X))^{1 / 2}$

$\psi=4 \pi L_{0}\left(1-\varepsilon_{0}\right) / S_{0}^{2}$

in which $\psi, L_{0}, \varepsilon_{0}, S_{0}$, and $S$ denotes a dimensionless parameter of porous structure, length per unit volume, porosity, initial surface area, and surface area at conversion $X$, respectively. Assuming that the reaction occurs on the solid surface and the pore is cylindrical hollow, Eq. (6) and (7) rewrites

$d X / d t=k_{p}(1-X)(1-\psi \ln (1-X))^{1 / 2}$

$\psi=1 / \rho_{t} V_{0}$.

The reaction rate constant $k_{p}$ is obtained by least square fitting of the Eq. (8) to the experimental gasification behavior. The $\psi$ is represented by using the true density $\rho_{t}$ and volume per unit gram $V_{0}$.

2.8 Oxygen uptake measurement of cedar wood char and cedar wood $\mathrm{HCl}$ char

$\mathrm{O}_{2}$-pulsed adsorption experiments were carried out to determine the carbon active sites of cedar wood char at different char conversion level. A $30 \mathrm{mg}$ of char was introduced into a flow type reactor and the outlet of the 


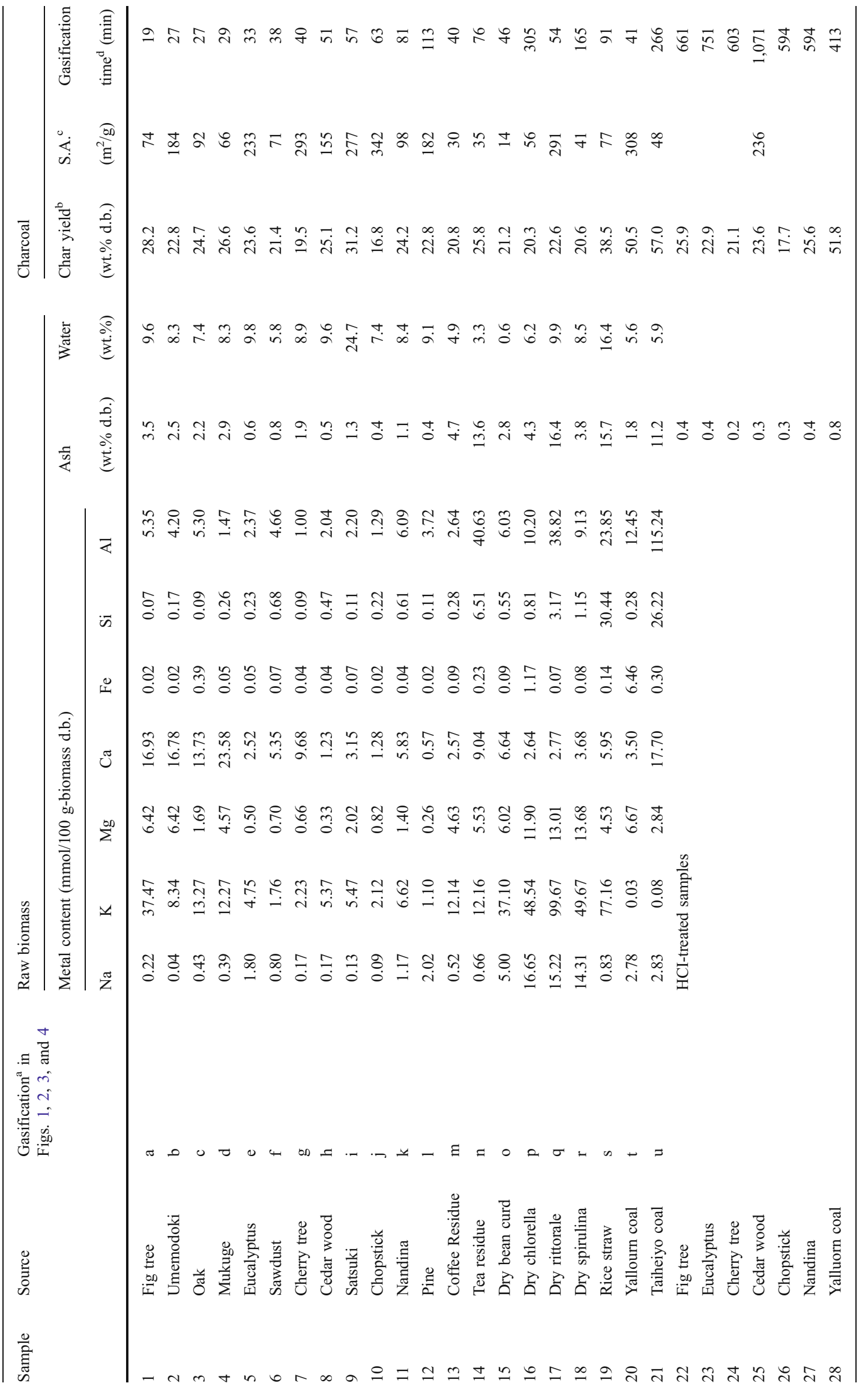


reactor was connected to a thermal conductivity detector used for a gas chromatograph. Pretreatment was carried out in a He stream at $650^{\circ} \mathrm{C}$ for $1 \mathrm{~h}$ (He flow rate, $20 \mathrm{~mL} / \mathrm{min}$ ). Then the sample was cooled down to $200^{\circ} \mathrm{C}$ and under steady flow of $\mathrm{He}(20 \mathrm{~L} / \mathrm{min}), \mathrm{O}_{2}(1 \mathrm{~mL} /$ pulse $)$ was pulsed with a pulse width of $2 \mathrm{~s}$ over the char until the detection responses became constant.

\section{Results and discussion}

\subsection{Physical properties and metal contents}

Table 1 summarizes indigenous metal constituents, ash and water in raw biomass, char yield, surface area and gasification time from various biomass sources. Biomass samples nos. 1 to 12 were arranged according to average gasification rate which was estimated from gasification time.

Water content was calculated by a weight loss from as received and crushed sample after drying at $107^{\circ} \mathrm{C}$ for $1 \mathrm{~h}$ in an oven, following the proximate analyses of coal sample. The amount of ash in the biomass was obtained by burning biomass chars in air flow after gasification experiments at $900^{\circ} \mathrm{C}$.

Metal contents in various types of biomass sources vary greatly. In woody biomass, potassium and calcium are the major catalytically active elements in gasification, and small amounts of silicon and aluminum are contained. On the contrary, herbaceous biomass and coal contain large quantities of silicon and aluminum. The microalgae biomass contains a great amount of ash.

Char yields of biomass at $1,000^{\circ} \mathrm{C}$ were $16-39$ wt.\% (d. b.), and these were smaller compared to those of coals (5057 wt.\% (d.b.)), due to higher oxygen content of biomass. On the other hand, char yields of demineralized biomass were slightly larger than those of raw biomass.

Surface areas of biomass chars obtained from nitrogen adsorption at $-196^{\circ} \mathrm{C}$ were in the range of $66-342 \mathrm{~m}^{2} / \mathrm{g}$. However, surface areas calculated from carbon dioxide adsorption at $0^{\circ} \mathrm{C}$ are higher than those observed for nitrogen. The surface areas calculated from carbon dioxide
Fig. 1 Change in gasification rate of various biomass chars, char: $10 \mathrm{mg}$, heating rate: $20^{\circ} \mathrm{C} /$ min, in $\mathrm{N}_{2}$ : Gasification $900^{\circ} \mathrm{C}$, $\mathrm{CO}_{2} 30 \mathrm{~mL} / \mathrm{min}$
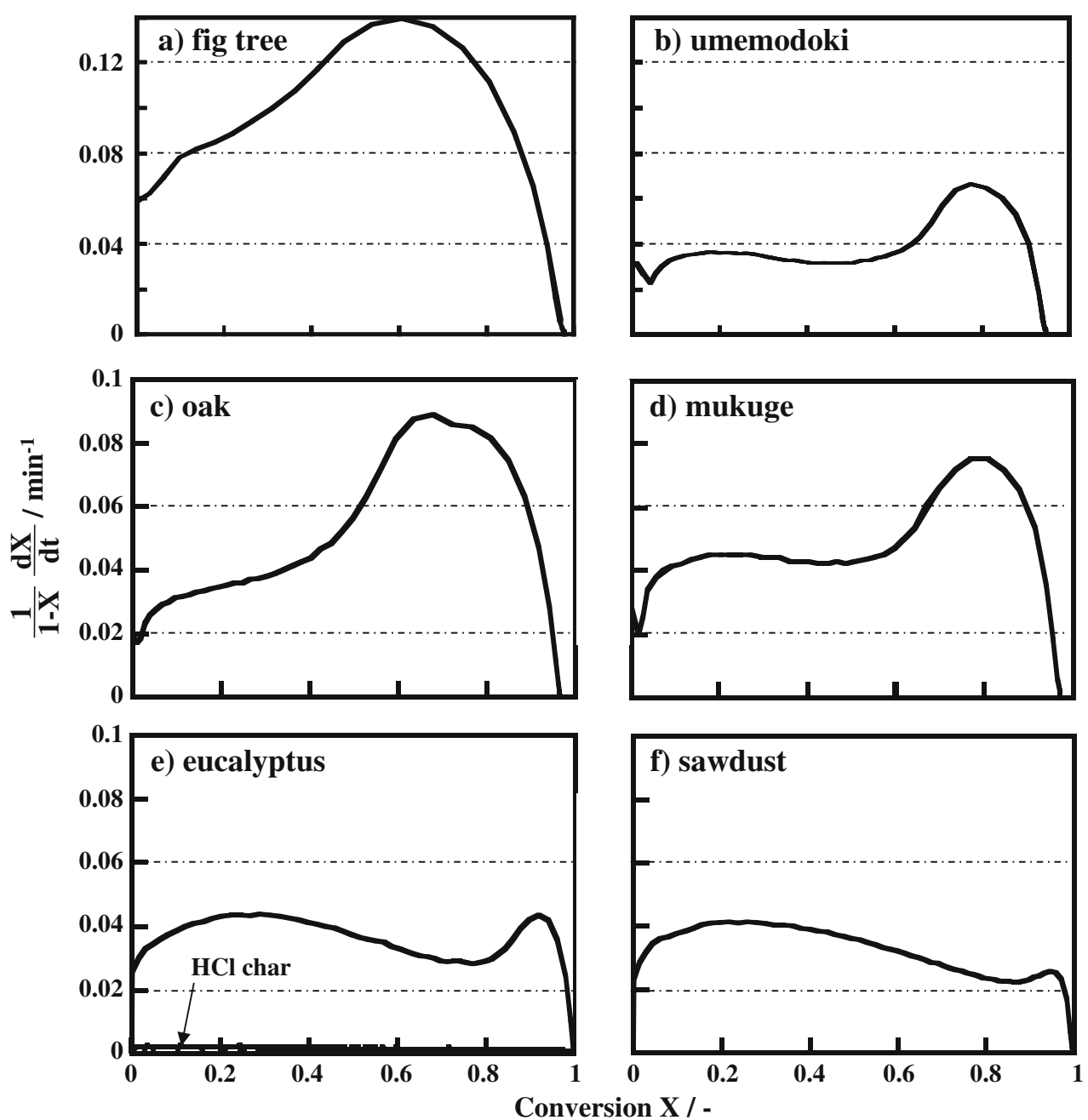
adsorption of cedar wood char, cedar wood treated $\mathrm{HCl}$ char and fig tree char were nearly ten times (879-1,144 $\mathrm{m}^{2}$ / g) as large as those calculated from nitrogen adsorption. It is said that pore diameter of char is mostly the same size as the gas molecule, and therefore, nitrogen takes a long time to diffuse into the pores [32]. Here, the surface areas calculated from nitrogen at $196^{\circ} \mathrm{C}$ were compared and the pore volume $V_{0}$ obtained from carbon dioxide adsorption at $0^{\circ} \mathrm{C}$ was employed for kinetic model parameters.

According to XRD measurements of various biomass chars, very broad and weak peaks ascribed to diffraction of graphite (002) and (100) were observed at $2 \theta=26.5^{\circ}$ and $43.5^{\circ}$, indicating that all the biomass chars have amorphous structure. Therefore, it is obvious that the graphite structure did not grow in chars prepared here.

\subsection{Gasification of various biomass chars}

Gasification behavior of biomass chars and coal chars is shown in Figs. 1, 2, 3, and 4. Gasification behavior of chars was classified into 3 groups, as follows: (1) the gasification rate reached a maximum in the higher conversion region $(X=$ 0.6-0.85), e.g., fig tree (no. 1; Fig.1a)), oak (no. 3; Fig. 1c), cedar wood (no. 8; Fig. 2h), satsuki (no. 9; Fig. 2i), nandina (no. 11; Fig. 2k), pine (no. 12; Fig. 21), coffee residue (no.13; Fig. $3 \mathrm{~m}$ ), green tea residue (no. 14 Fig. $3 n$ ), and dry bean curd (no. 15; Fig. 3o) (2) the gasification rate profile showed two peaks, e.g., umemodoki (no. 2; Fig. 1b), mukuge (no. 4; Fig. 1d), eucalyptus (no. 5; Fig. 1e), sawdust (no. 6; Fig. 1f), cherry tree (no. 7 Fig. 2g), and chopstick (no. 10; Fig. 2j); (3) gasification rates did not show sharp increases, e.g., dry chrorella (no. 16; Fig 3p), dry rittorale (no. 17; Fig. 3r), dry spirulina (no. 18; Fig. 3q), rice straw (no.19; Fig. 4s) Yallourn (no. 20; Fig. 4t), and Taiheiyo coal (no.20; Fig 4u).

As a representative of group (1), cedar wood (sample 8, Fig. $2 \mathrm{~h}$ ) is a typical woody biomass abundant in forest in Japan. The gasification rate of the char increased at initial stage and remained nearly constant to char conversion of $70 \%$. Gasification rate increased rapidly at above the conversion $X$ of 0.7 and a maximum rate was obtained at $X$ of around 0.8. Well-known kinetic models like the random pore model proposed by Bhatia and Perlmutter fail
Fig. 2 Change in gasification rate of various biomass chars (continued from Fig. 1). Conditions are the same as shown in the caption to Fig. 1
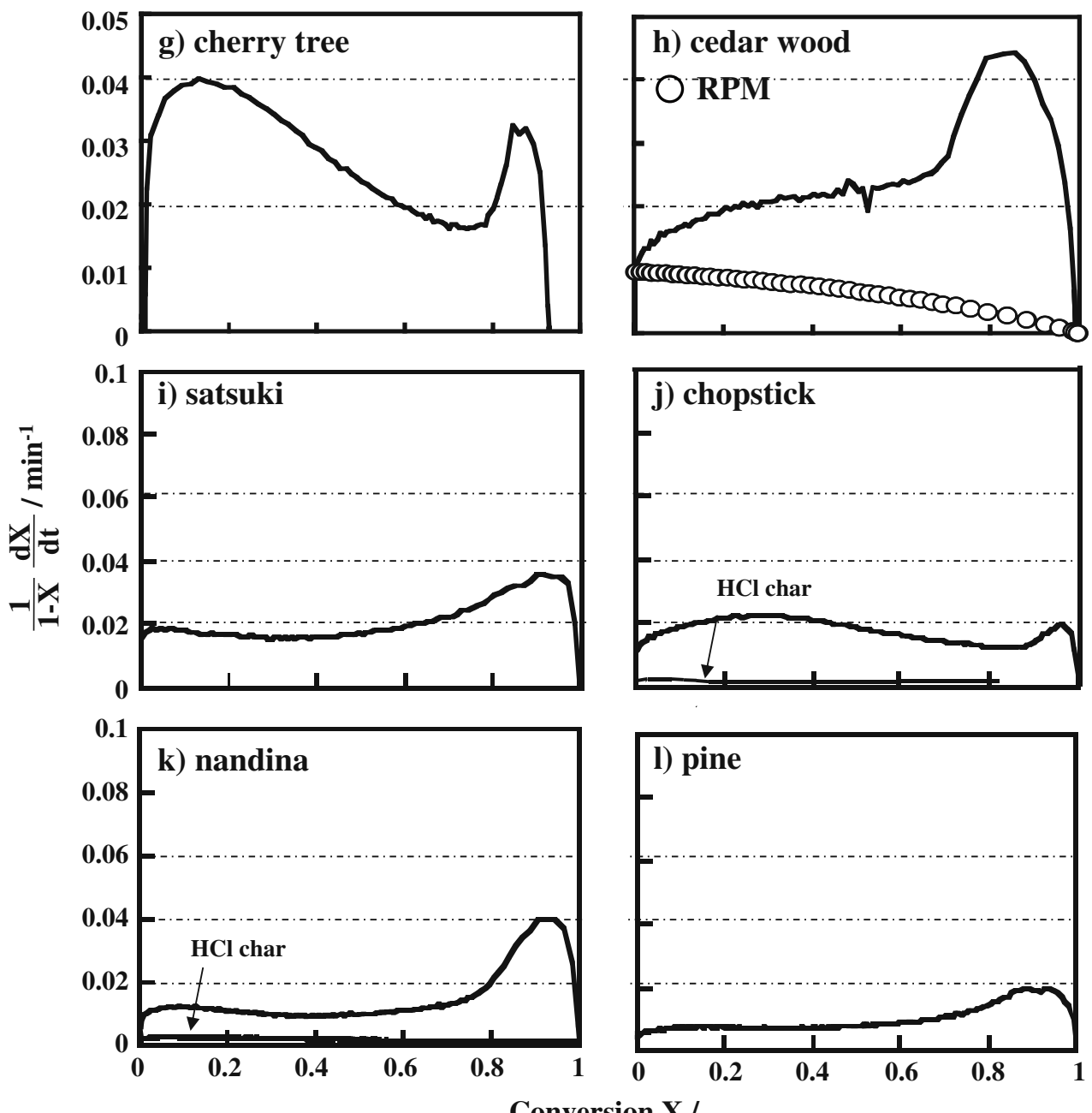
Fig. 3 Change in gasification rate of various biomass chars (continued from Fig. 1). Conditions are the same as shown in the caption to Fig. 1
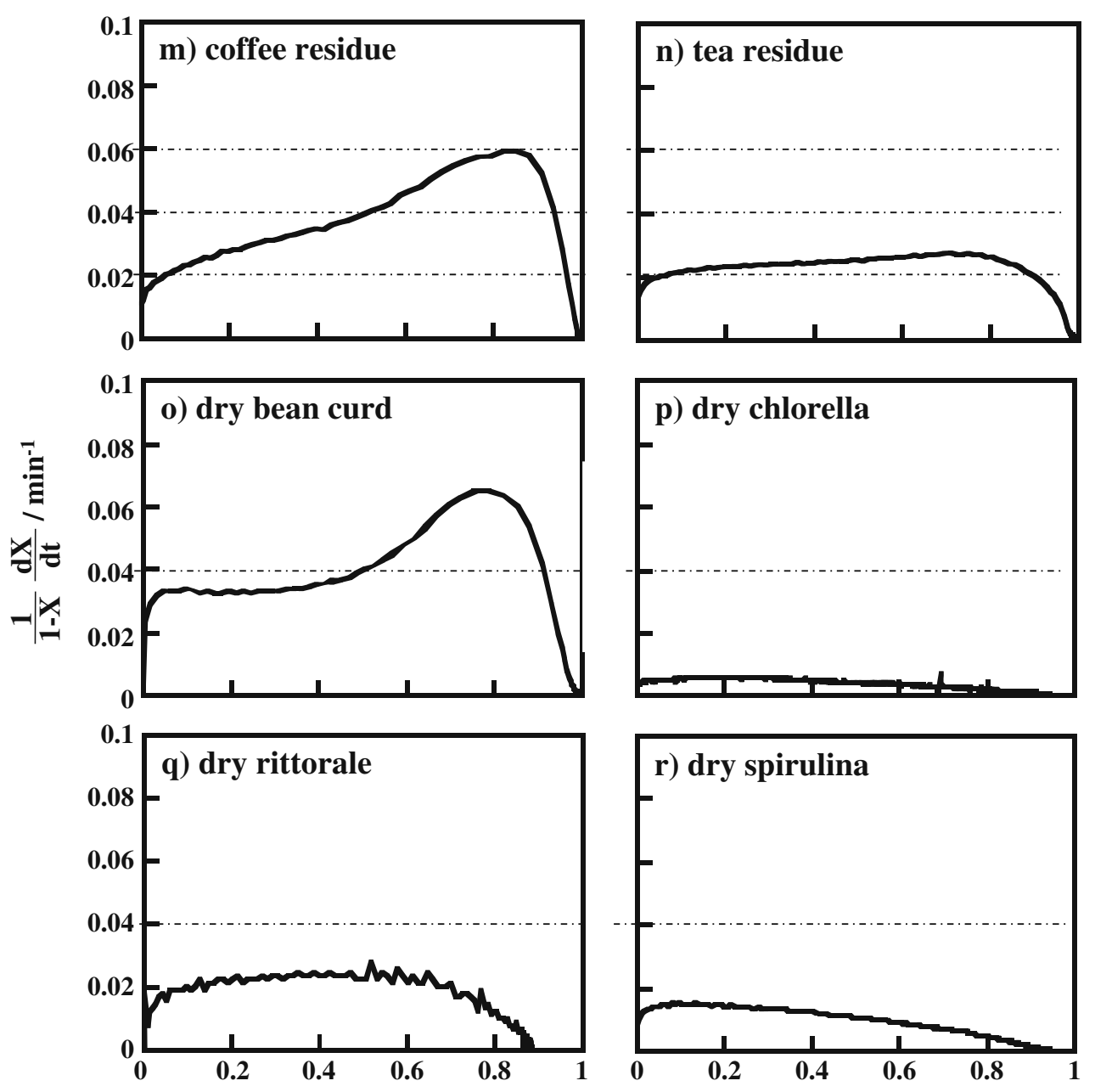

Conversion X / -

to describe the pronounced acceleration in the reaction rates. Fig tree char (group (1)) showed the largest gasification rate among all the samples (sample 1, Fig. 1a). Since fig tree contains a large amount of potassium and calcium (especially potassium), indigenous metals seemed to catalyze the gasification of char. A relatively large content of potassium in the char is characteristic of group (1).

As a representative of group (2), umemodoki and cherry tree samples 2 and 7, (Fig. 1d and Fig. 2g) contained both large amounts of potassium and calcium, and exhibited higher $\mathrm{Ca} / \mathrm{K}$ ratio. The gasification rate profiles of these chars exhibited two peaks at $X=$ around 0.2 (not remarkable) and 0.8 , and this profile did not also fit the random pore model.

The gasification behavior of rice straw containing a large amount of potassium (group (3), sample 19, Fig. 4s) exhibited similar behavior to that of Taiheiyo coal (sample 21, Fig. 4u). However, rice straw originally contains significant amounts of silica, and as a result, during the pyrolysis of the biomass, silica may deactivate potassium by forming catalytically inactive potassium silicate, leading to reduced char gasification rates $[30,33]$. The microalgae biomass chars contained a large amount of metals, but the chars showed low reactivity (Fig. 3q, r). Alkali and alkaline earth metals exist in the form of chloride, so that the metals did not exhibit catalytic activity during gasification. In general, samples belong to this group (3) originally contained larger amount of $\mathrm{SiO}_{2}$ and/or $\mathrm{Al}_{2} \mathrm{O}_{3}$, which form(s) complex oxides with catalytically active elements to give catalytically inactive oxide.

No correlation between the surface area of chars and gasification rate (estimated by gasification time) were seen indicating that mineral matters of biomass seemed to affect gasification rate more pronouncedly than the surface areas of chars.

\subsection{Gasification of $\mathrm{HCl}$-treated biomass chars}

Figure 5 shows the gasification behavior of demineralized cedar wood char (sample 25). Compared to Fig. 2h, it is evident that the absence of indigenous mineral matters in cedar wood $\mathrm{HCl}$ char led to a markedly decreased 

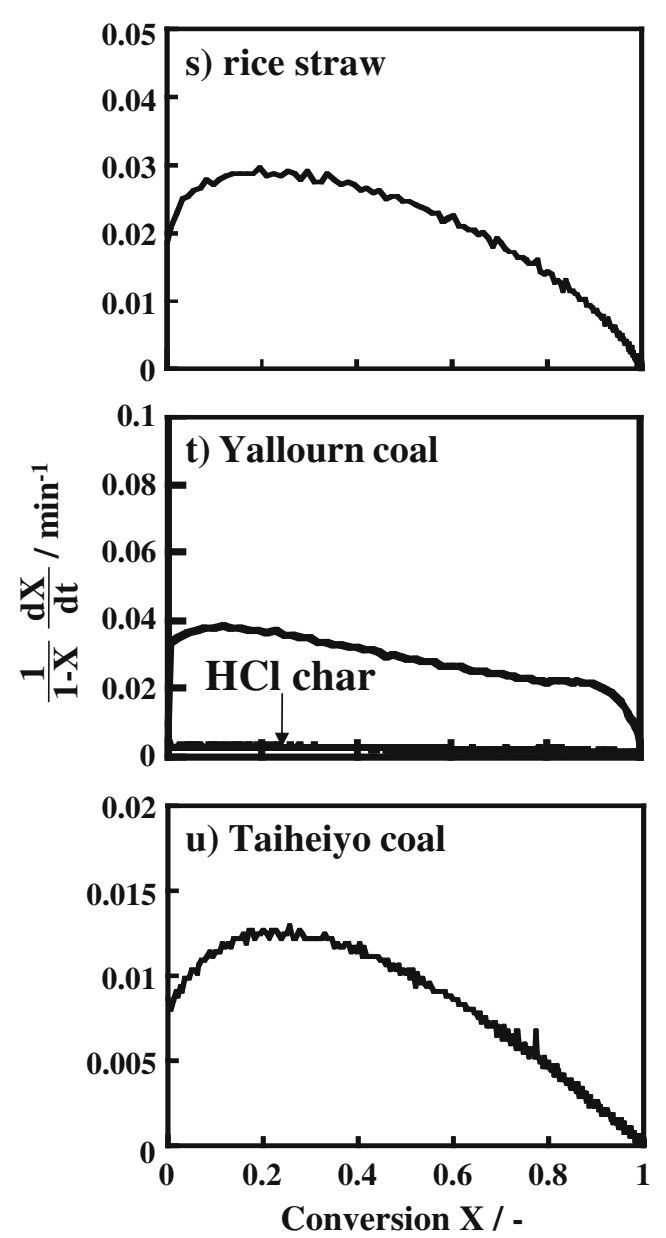

Fig. 4 Change in gasification rate of various biomass chars (continued from Fig. 1). Conditions are the same as shown in the caption to Fig. 1

gasification rate as compared with that of the original one (ca. $1 / 20$ at $X=0.5$ ). Especially, a steep rise in the gasification rate of cedar wood char conversion at $X$ near 0.7 disappeared. Thus, the random pore model fitted well with experimental results, and predicted gasification time of

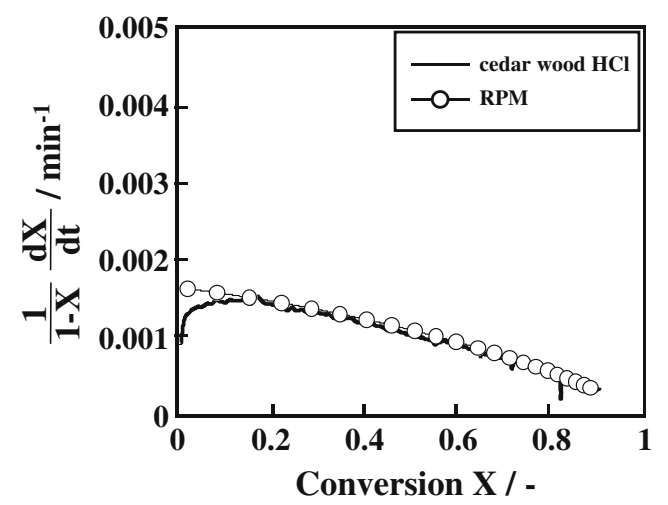

Fig. 5 Change in gasification rate of HCl-treated cedar wood char and simulation by random pore model (open circles). Conditions are the same as shown in the caption to Fig. 1
1,050 min at $X$ of 0.95 was in good agreement with the experimental gasification time of 1,071 min (Table 1). The indigenous mineral matters such as alkali and alkaline earth metals in the biomass were easily removed from the biomass, but the silica and alumina originally contained in the biomass were difficult to remove and remained in the char. Therefore, it is apparent that the decrease in the gasification rate may be attributed to removal of alkali and alkaline earth metals.

3.4 Re-impregnation of alkali and alkaline earth metals to demineralized cedar wood

In order to understand the catalytic effects of the mineral matters in detail, addition of sodium, magnesium, iron, potassium, and calcium to demineralized cedar wood was examined. Figure 6 summarizes gasification behavior of demineralized cedar wood char after impregnating the same amounts of metal salts which were found in the original cedar wood. The term "raw" in Fig. 6 indicates the gasification behavior of the char prepared by impregnating metals with demineralized raw biomass before carbonization, and "char" indicates behavior of the char of which impregnation of metals was done after carbonization of demineralized biomass. The char impregnated metals after carbonization of $\mathrm{HCl}$-treated cedar wood showed lower reactivity than the char impregnated before carbonization.

In the gasification of sodium-impregnated char, no catalytic effect of sodium was observed at such loading levels. Magnesium and iron increased the gasification rate at $\mathrm{X}$ below 0.2 , and the gasification behavior of magnesium and ironimpregnated char did not agree with that of the char prepared from the untreated cedar wood. In particular, very high initial gasification rate of iron-loaded case should be noted [14]. Metallic iron exhibits high catalytic activity but with other metal salts, its activity was lost by forming complex metal oxides of iron [14]. Due to very small content of iron in cedar wood, further studies were not done with iron.

When potassium and calcium were impregnated, the gasification rate was enhanced and maximum rates were obtained at $X$ about 0.3 and 0.9 , respectively.

Since potassium and calcium increased gasification rate markedly, the effects of the loading level of calcium and potassium catalyst were examined. Loading of a small amount of $\mathrm{Ca}(0.62 \mathrm{mmol})$ did not increase gasification rate. In contrast, the gasification rate increased with increasing loading level of calcium to 1.23 and $2.46 \mathrm{mmol} / 100$ g-biomass. A relatively broad peak in the gasification rates were observed around $X=0.2$ to 0.35 (Fig. 7a). However, gasification rate decreased with an increase in the $X$ above 0.5 and $X$ above 0.8 the activity of $\mathrm{Ca}$ was completely lost. Calcium exists in the form of calcium oxide in the char, and this oxide sintered gradually 
Fig. 6 Change in gasification rate of various mineral matters loaded on HCl-treated cedar wood. Raw indicates loading of metals to demineralized biomass and char indicates loading of metal to demineralized char. Conditions are the same as shown in the caption to Fig. 1
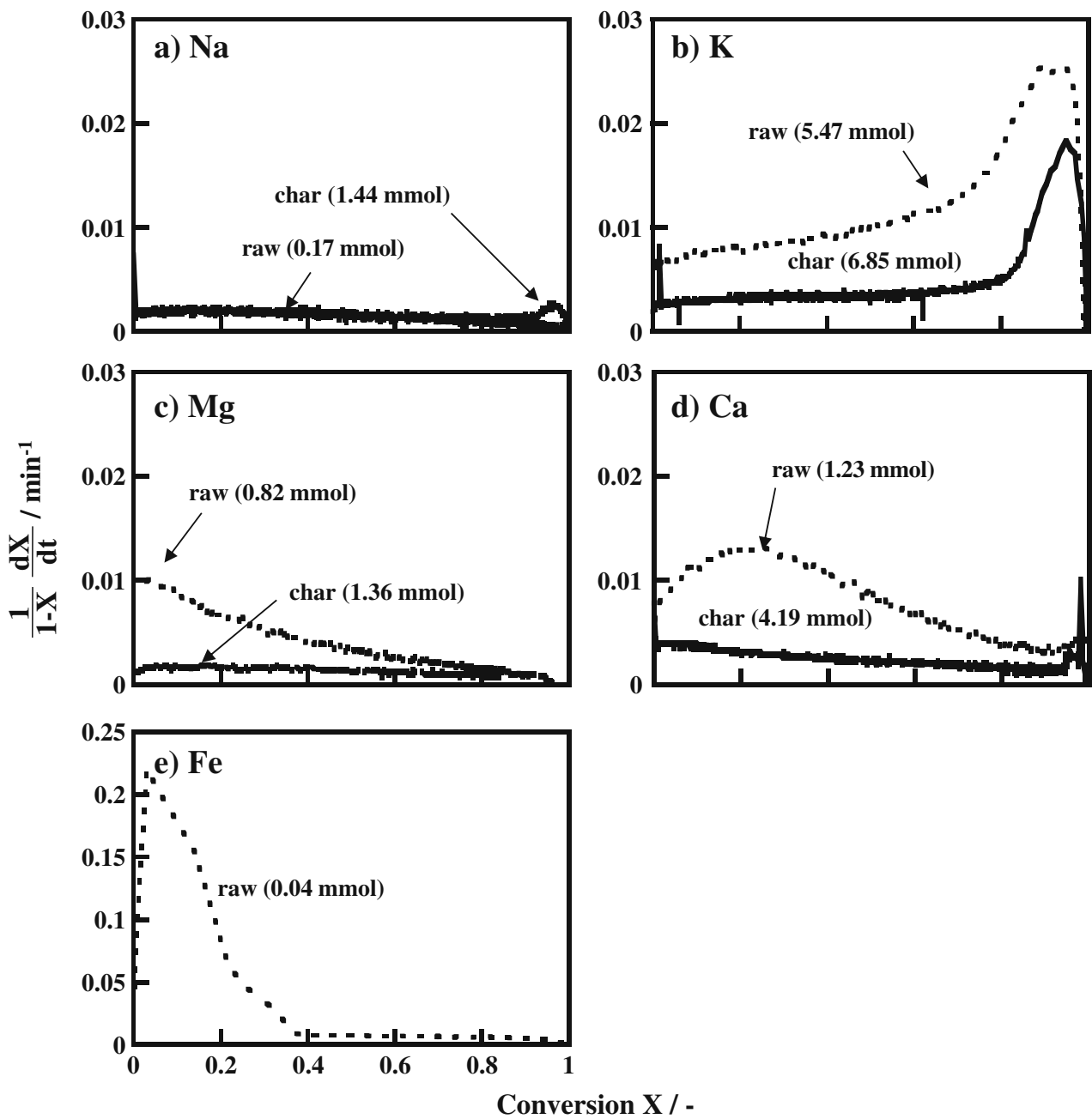

during the gasification with a loss of carbon which supported $\mathrm{Ca}$. Sintering of $\mathrm{Ca}$ was evidenced by XRD measurement after gasification.

On the contrary, the potassium catalyst promoted the gasification rate gradually (Fig. 7b), a steep rises at the higher conversion ( $X>0.7 ; 5.37 \mathrm{mmol}$ and $X>0.5 ; 10.7 \mathrm{mmol}$ ) were observed as well as in the gasification behavior of untreated cedar wood char. The maximum gasification rate increased in proportion to the loading level of potassium.

When $\mathrm{K}$ and $\mathrm{Ca}$ were co-loaded, almost the same gasification behavior of the untreated cedar wood was reproduced (Fig. 7c). From these observations, it is obvious that the gasification of biomass char depends strongly on the catalytic effects of potassium and calcium.

\subsection{Oxygen uptake measurement of cedar wood char} and $\mathrm{HCl}$-treated cedar wood char

We have previously studied catalytic $\mathrm{CO}_{2}$ gasification of carbon materials loaded with alkali metals and alkaline earth metals, using $\mathrm{C}-13$ isotope labeled $\mathrm{CO}_{2}\left({ }^{13} \mathrm{CO}_{2}\right)$ pulsed reaction technique. In the pulsed reaction technique, time resolved information of adsorption and reactions on to the catalyst and carbon materials could be obtained ${ }^{1}$.

The mechanism of alkali metal catalysis in the $\mathrm{CO}_{2}$ gasification of carbon is complex, but has been proposed as the following simplified oxygen-transfer processes [34].

$$
\begin{aligned}
& \mathrm{M}_{x} \mathrm{O}_{y}+{ }^{13} \mathrm{CO}_{2} \longrightarrow \mathrm{M}_{x} \mathrm{O}_{y+1}+{ }^{13} \mathrm{CO} \\
& \mathrm{M}_{x} \mathrm{O}_{y+1}+\mathrm{C}_{n} \longrightarrow \mathrm{M}_{x} \mathrm{O}_{y}+{ }^{12} \mathrm{CO}+\mathrm{C}_{n-1}
\end{aligned}
$$

\footnotetext{
${ }^{1}$ Pulsed reaction is one of unsteady-state operation of reactions. In a fixed bed reactor, a certain amount of reactant (char this case) was charged, and under a steady flow of an inert carrier gas (He, Ar), a small amount of reactant was injected as a pulse (width about $1 \mathrm{~s}$ ). The effluent was analyzed with a quadrupole mass spectrometer within time resolution less than $1 \mathrm{~s}$. From the response of the unreacted reactant and products, we can evaluate rapid dynamic behavior of adsorption and reaction. Especially important information is obtained using isotope labeled samples. Here we can differentiate $\mathrm{CO}$ from char natural ${ }^{12} \mathrm{C}$ and ${ }^{13} \mathrm{CO}$ from reactant ${ }^{13} \mathrm{CO}_{2}$.
} 

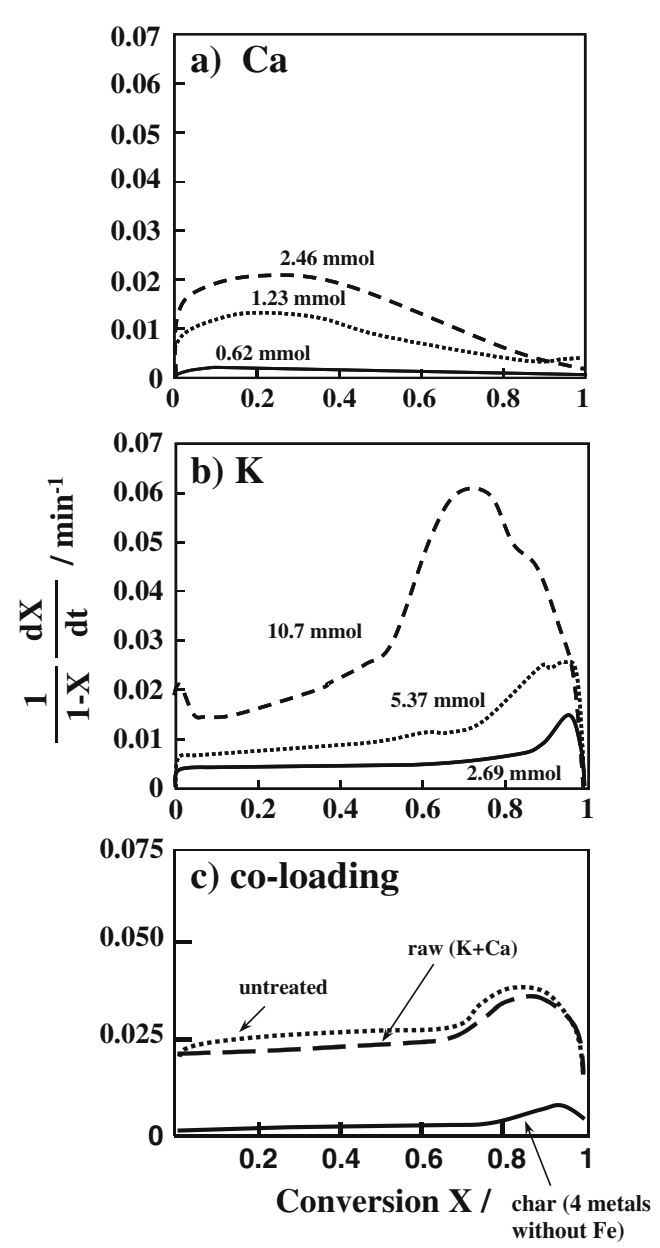

Fig. 7 Loading level of $\mathrm{K}$ and $\mathrm{Ca}$ and co-loading to $\mathrm{HCl}$-treated cedar wood. Conditions are the same as shown in the caption to Fig. 1

The rate of reaction (10), oxidation of catalytically active lower valence metal oxide or metal $(y=0)$ was almost the same order among the alkali metals. However, irrespective of carbon species following order was observed; $\mathrm{Li}>\mathrm{Na}>\mathrm{K}$. On the contrary, the rate of reaction (11), which is oxygentransfer reaction from the catalyst to carbon $(\mathrm{Cn})$, varied significantly and the order was $\mathrm{K}>\mathrm{Na}>\mathrm{Li}$. From these results, it was shown that $\mathrm{K}$ is the most active catalyst in the $\mathrm{CO}_{2}$ gasification of carbon [34].
In the $\mathrm{Ca}$ loaded case, much more complicated reaction sequences were proposed:

$(\mathrm{CaO})_{n}+{ }^{13} \mathrm{CO}_{2} \longrightarrow \mathrm{CaOO}(\mathrm{CaO})_{n}+{ }^{13} \mathrm{CO}$

$\mathrm{CaOO}(\mathrm{CaO})_{n}+\mathrm{C}_{n} \longrightarrow(\mathrm{CaO})_{n}+{ }^{12} \mathrm{CO}+\mathrm{C}_{n-1}$

where $(\mathrm{CaO})_{n}$ indicates $\mathrm{CaO}$ cluster on carbon. Thus only a part of loaded $\mathrm{CaO}$ could react with gas phase $\mathrm{CO}_{2}$ [35]. Thus the catalytic activity of calcium is smaller than that of potassium.

In the gasification of biomass char, potassium catalyst disperses well on carbon up to atomic level, since it is in liquid or vapor state at a gasification temperature [36, 37]. Thus contact between metal and carbon is possible, irrespective of carbon conversion. Since the metal-to-carbon ratio increases constantly with progress in the gasification, the gasification rate should continue to increase until the end of gasification. However, the gasification rate reached a maximum at $X$ of around 0.7 in the gasification of the cedar wood char. In order to examine this phenomenon in detail, the untreated cedar wood char and the HCl-treated char at conversion levels of $0.2,0.6$, and 0.7 were prepared and the oxygen pulsed adsorption technique was applied to determine the amount of $\mathrm{O}_{2}$ chemisorption $\left(\mathrm{O}_{2}\right.$ uptake), which will approximately correspond to the number of active sites on carbon [38]. Although this must be done with $\mathrm{CO}_{2}$ as adsorbent, the reactivity of $\mathrm{CO}_{2}$ at a low temperature is very low to be accurately measured. The amount of $\mathrm{O}_{2}$ uptake should reflect the amount of free carbon active sites in the char. Table 2 shows $\mathrm{O}_{2}$ uptake of the chars at various conversion levels of char together with gasification rate at respective char conversion.

$\mathrm{O}_{2}$ uptake of the untreated char was much larger than that of the $\mathrm{HCl}$-treated char. $\mathrm{O}_{2}$ uptake of the $\mathrm{HCl}$-treated cedar wood original char of $23 \mu \mathrm{mol} \mathrm{g}{ }^{-1}$ increased to $31 \mu \mathrm{mol} \mathrm{\textrm {g } ^ { - 1 }}$ increasing $X$ to 0.24 . About 1.3 times increase in the $\mathrm{O}_{2}$ uptake corresponds to the increase in the gasification rate $X$ of 0 to 0.24 (1.4 times increase). Further increase in the conversion $X$ to $0.64, \mathrm{O}_{2}$ uptake
Table 2 Comparison of surface area, $\mathrm{O}_{2}$ uptake, and gasification rate

${ }^{\text {a }}$ Gasification rate at char conversion $X$ in the first column

\begin{tabular}{llccccc}
\hline Sample & $\begin{array}{l}X \\
(-)\end{array}$ & $\begin{array}{l}\text { S.A. } \\
\left(\mathrm{m}^{2} / \mathrm{g}\right)\end{array}$ & $\begin{array}{l}\mathrm{O}_{2} \text { uptake } \\
(\mu \mathrm{mol} / \mathrm{g} \text { char })\end{array}$ & $\begin{array}{l}\text { Gasification rate }^{\mathrm{a}} \\
\mathrm{min}^{-1} / 10^{3}\end{array}$ & $\begin{array}{l}\mathrm{K} / \mathrm{C} \\
\mathrm{mol} / \mathrm{mol} \times 10^{3}\end{array}$ \\
\hline HCl-cedar wood & 0 & 236 & 23 & 1.0 & \\
& 0.24 & 1,001 & 31 & 1.4 & & \\
& 0.62 & 2,761 & 25 & 0.9 & & \\
Cedar wood & 0 & 155 & 116 & 10 & 2.63 & 0.60 \\
& 0.24 & 778 & 221 & 20 & 3.47 & 0.79 \\
& 0.62 & 756 & 325 & 24 & 6.94 & 1.59 \\
& 0.73 & 1,016 & 419 & 32 & 9.80 & 2.23 \\
\hline
\end{tabular}


decreased to $25 \mu \mathrm{mol} \mathrm{g}^{-1}$ and during this stage gasification rate decreased from 1.4 to $0.9 \times 10^{-3} \mathrm{~min}^{-1}$. The surface area of char increased markedly with an increase in the conversion of char. The amount of free carbon active sites should increase with an increase in the surface area of the char. However, this was not seen as shown in Table 2, and considerably good correlation between $\mathrm{O}_{2}$ uptake and gasification rate was observed, indicating that free carbon active site measured by $\mathrm{O}_{2}$ uptake is an appropriate index of reactivity to demineralized biomass derived char.

On the other hand, $\mathrm{O}_{2}$ uptake of the untreated cedar wood char increased with an increase in the surface area together with increases in the char conversion level. Assuming that devolitilization of catalytically active potassium from char during gasification did not occur, $\mathrm{K} / \mathrm{C}$ and $\mathrm{Ca} / \mathrm{C}$ ratios increased markedly with increases in the char conversion (Table 2). Together with increases in the surface area of char, numbers of carbon nearby potassium and calcium might have increased. Thus, numbers of carbon active site contacting potassium increased to accelerate carbon gasification rate. This may be pronounced above a conversion 0.6-0.8. Struis et al. explained similar phenomenon as follows: alkaline accumulation in the char, superimposed on structural change in micropore domain [27]. Above conversion 0.9, a decrease in the gasification rate was remarkable. This seems to be ascribed to following two possibilities: (1) Even at a high catalyst to carbon ratio, the amount of carbon to be gasified decreased to small amount and it would be coated with catalyst. As a result, access of $\mathrm{CO}_{2}$ to carbon reaches rate controlling step. (2) Due to high vapor pressure of alkali metal, evaporation of a certain amount of alkali metal from carbon proceeded at a late stage of the gasification.

\section{Conclusions}

Gasification behavior of various biomass chars was investigated. The gasification rate was affected by indigenous mineral matter content of calcium and potassium. A steep rise in the gasification rte at a higher conversion region of 0.8 was observed for many biomass chars. It was assumed to be caused by potassium catalyst moving to the active free carbon sites made available by the fragmentation of carbon structure. Several biomass containing a large amount of calcium in addition to potassium exhibited increase in gasification rate at a char conversion of around 0.2 . Calcium catalyzed gasification of biomass char, only at an early stage the reaction. However, char containing $\mathrm{SiO}_{2}$ completely deactivated catalytic effect of potassium by forming silicate complex oxide. Results of $\mathrm{O}_{2}$ uptake by pulse techniques reflect the gasification rate, and the increase in free carbon active sites with an increase in the conversion.

List of symbols

$\mathrm{C}_{\mathrm{f}} \quad$ Free carbon active site

$\mathrm{C}(\mathrm{O})$ Occupied carbon active site

$\mathrm{C}_{n} \quad$ Solid carbon (char)

$L_{0} \quad$ Initial pore depth $m$

$R \quad$ Gasification rate per minute

$S \quad$ Surface area of char at conversion $X$ square meters per gram

$S_{0} \quad$ Initial surface area of char square meters per gram

$X \quad$ Char conversion

$\psi \quad$ Structural parameter defined by Eq. (7)

$\varepsilon_{0} \quad$ Porosity cubic centimeter per gram

\section{References}

1. Yoshitaka M (2005) Biomass CDM and sink CDM. J Jpn Inst Energy 84:815-820

2. Ragauskas AJ, Williams CK, Davison BH, Britovsek G, Cairney J, Eckert CA, Frederick WJ Jr, Hallett JP, Leak DJ, Liotta CL (2006) The path forward for biofuels and biomaterials. Science 311(5760):484-489

3. Bridgwater AV (1995) A techno-economic comparison of power production by fast biomass fast pyrolysis with gasification and combustion. Fuel 74:631-653

4. Bridgwater AV, Toft AJ, Brammer JG (2002) The technical and economic feasibility of biomass gasification for power generation. Renewable Sustainable Energy Rev 6:181-248

5. Kirubakaran V, Sivaramakrishnan V, Nalini R et al (2009) A review on gasification of biomass. Renewable Sustainable Energy $13: 168-175$

6. Laine NR, Vastola FJ, Walker PL Jr (1963) The importance of active surface area in the carbon-oxygen reaction. J Phys Chem 67:2030-2034

7. Radovic LR, Walker PL Jr, Jenkins RG (1983) Importance of carbon active sites in the gasification of coal chars. Fuel 62:849856

8. Takeda S, Kitano K, Kubota J, Kawabata J (1985) Effect of coal nature on intrinsic reaction rate of the coal char gasification by $\mathrm{CO}_{2}$. Nenryo Kyokaishi 64:409-418

9. Tomita A, Oikawa Y, Kanaia T, Tamai Y (1976) Gasification of coals treated with non-aqueous solvents. 6. Catalytic steam gasification at atmospheric pressure. Fuel 55:211-216

10. Haynes WP, Gasior SJ, Forney AJ (1974) Catalysis of coal gasification at elevated pressure. Adv Chem Ser 131:179-202

11. McKee DW (1974) Effect of metallic impurities on the gasification of graphite in water vapor and hydrogen. Carbon 12:453-464

12. Baker RTK, Chludzinski JJ Jr, Sherwood RD (1985) A comparison of the catalytic influence of nickel, iron and nickel-iron on the gasification of graphite in various gaseous environments. Carbon 23:245-254

13. Inui $T$, Otowa $T$, Okazumi $F$ (1985) Gasification of active carbon by iron-based composite catalysts for obtaining directly a gas of optional ratio. Carbon 23:193-208

14. Tanaka S, U-emura T, Ishizaki K, Nagayoshi K, Ikenaga N, Ohme $\mathrm{H}$, Suzuki T, Yamashita H, Ampo M (1995) $\mathrm{CO}_{2}$ Gasification of 
iron-loaded carbons - activation of the iron catalysts with CO. Energy Fuels 9:45-52

15. Kayembe N, Pulsifer AH (1976) Kinetics and catalysis of the reaction of coal char and steam. Fuel 55:211-216

16. Veraa MJ, Bell AT (1978) Effect of alkali metal catalysts on gasification of coal char. Fuel 57:194-200

17. Hüttinger KJ, Hüttinger KJ, Roland Minges R (1985) Water vapour gasification of carbon: improved catalytic activity of potassium chloride using anion exchange. Fuel 64:486-490

18. Takarada T, Nabatame T, Ohtsuka Y, Tomita A (1987) Utilization of nacl as a catalyst precursor for catalytic gasification of low-rank coal. Energy Fuels 1:308-309

19. Takarada T, Nabatame T, Ohtsuka Y, Tomita A (1989) Steam gasification of brown coal using sodium-chloride and potassiumchloride catalysts. Ind Eng Chem Res 28:505-510

20. McKee DW (1980) Catalytic effects of alkaline earth carbonates in the carbon-carbon dioxide reaction. Fuel 59:308-314

21. Yamada T, Honma T, Suzuki T (1983) Catalytic behvior of alkaline erth metal compounds on carbon and carbon dioxide reaction. Nenryo Kyokaishi 62:974-981

22. Hashimoto K, Miura K, Xu JJ (1987) Gasification reactivity of various coals at a high temperature. Nenryo Kyokaishi 66:418426

23. Sutton D, Kelleher B, Ross JRH (2001) Review of literature on catalysts for biomass gasification. Fuel Process Technol 73:155173

24. Szekely J, Evans JJ (1971) A structural model for gas-solid reactions with a moving boundary-II: the effect of grain size, porosity and temperature on the reaction of porous pellets. Chem Eng Sci 26:1901-1913

25. Sahimi M, Gavalas GR, Tsotsis TT (1990) Statistical and continuum models of fluid-solid reactions in porous media. Chem Eng Sci 45:1443-1502
26. Bhatia DK, Perlmutter DD (1980) A random pore model for fluidsolid reactions: i. Isothermal, kinetic control. AIChE J 26:379-386

27. Struis RPWJ, Stucki CSS, Prins R (2002) Gasification reactivity of charcoal with $\mathrm{CO}_{2}$. Part II: metal catalysis as a function of conversion. Chem Eng Sci 57:3593-3602

28. Standish N, Tanjung AFA (1988) Gasification of single wood charcoal particles in carbon dioxide. Fuel 67:666-672

29. Hamilton RT, Sams DA, Shadman F (1984) Variation of rate during potassium-catalysed $\mathrm{CO}_{2}$ gasification of coal char. Fuel 63:1008-1012

30. Wood BJ, Sancier KM (1984) The mechanism of the catalytic gasification of coal char-a critical review. Catal Rev Sci Eng 26:233-279

31. Zhang Y, Ashizawa M, Kajitani S, Miura K (2008) Proposal of a semi-empirical kinetic model to reconcile with gasification reactivity profiles of biomass chars. Fuel 87:475-481

32. Gan H, Nandi SP, Walker PL Jr (1972) Nature of the porosity in American coals. Fuel 51:272-277

33. Kannan MP, Richards GN (1990) Gasification of biomass chars in carbon dioxide: dependence of gasification rate on the indigenous metal content. Fuel 69:747-753

34. Suzuki T, Ohme H, Watanabe Y (1992) Alkali metal catalyzed carbon dioxide gasification of carbon. Energy Fuels 6:343-351

35. Suzuki T, Ohme H, Watanabe Y (1994) Mechanisms of alkaline-earth metals catalyzed $\mathrm{CO}_{2}$ gasification of carbon. Energy Fuels 8:649-658

36. Cerfontain MB, Moulijn JA (1986) The interaction of $\mathrm{CO}_{2}$ and $\mathrm{CO}$ with an alkali carbonate carbon system studied by in-situ fourier transform infrared spectroscopy. Fuel 65:1349-1355

37. Takarada T, Ogiwara M, Kato K (1992) Catalytic steam gasification of coal by physical mixing of K-exchanged brown coal. J Chem Eng Jpn 25:44-48

38. Nandi SP, Walker PL Jr (1975) Carbon molecular sieves for the concentration of oxygen from air. Fuel 54:169-178 